\title{
No regrets? An investigation of the relationship between being laid off and experiencing career regrets
}

\author{
Sherry E. Sullivan \\ Monica L. Forret \\ Lisa A. Mainiero \\ Fairfield University, Imainiero@fairfield.edu
}

Follow this and additional works at: https://digitalcommons.fairfield.edu/business-facultypubs Copyright 2007 Emerald Publishing

\section{Peer Reviewed}

\section{Repository Citation}

Sullivan, Sherry E.; Forret, Monica L.; and Mainiero, Lisa A., "No regrets? An investigation of the relationship between being laid off and experiencing career regrets" (2007). Business Faculty Publications. 59.

https://digitalcommons.fairfield.edu/business-facultypubs/59

\section{Published Citation}

Sherry E. Sullivan, Monica L. Forret, Lisa A. Mainiero, (2007) "No regrets? An investigation of the relationship between being laid off and experiencing career regrets", Journal of Managerial Psychology, Vol. 22 Iss: 8, pp.787 804

This item has been accepted for inclusion in DigitalCommons@Fairfield by an authorized administrator of DigitalCommons@Fairfield. It is brought to you by DigitalCommons@Fairfield with permission from the rightsholder(s) and is protected by copyright and/or related rights. You are free to use this item in any way that is permitted by the copyright and related rights legislation that applies to your use. For other uses, you need to obtain permission from the rights-holder(s) directly, unless additional rights are indicated by a Creative Commons license in the record and/or on the work itself. For more information, please contact digitalcommons@fairfield.edu. 
No Regrets? Examining the Relationship Between Career Strategies, Career Events, and Career Regrets

Manuscript submitted for consideration by the Journal of Managerial Psychology, November 9, 2006. 
No Regrets? Examining the Relationship Between Career Strategies, Career Events, and Career Regrets

\begin{abstract}
(word count 211)
Purpose - The purpose of this paper is to examine the regrets individuals experience about the career strategies they have used. Although a great deal of research has focused on strategies for career success, relatively little research has examined career missteps or career regrets.
\end{abstract}

Design/methodology/approach - Using a large internet sample of 1480 professionals, we explore the reasons why individuals experience different career regrets over time.

Findings - We found that people tend to experience two major types of regrets---regrets about objective career strategies (i.e., lack of networking, being more politically savvy) and regrets about subjective career strategies (i.e., taking more time to spend with family, pursuing more meaningful work), and the pattern of regrets varied by age.

Research limitations/implications - The findings may have limited generalizability because of the use of internet-based surveys and the use of a cross-sectional design.

Practical implications - Given the greater mobility of the laborforce and rapid changes in the work environment, studying career regrets may be increasingly important as individuals face more career choices, they may have more opportunities to experience regret.

Originality/value - This study contributes to a better understanding of a relatively unexplored topic and discusses implications for future research and practice.

Keywords - careers, regrets, success, boundaryless, work/family, protean Paper type - Research paper 
No Regrets? Examining the Relationship Between Career Strategies, Career Events, and Career Regrets

Despite decades of research on the subject of careers, there has not been a systematic exploration of career regrets. Given the constant restructuring and re-engineering of organizations (Arthur \& Rousseau, 1996), demographic shifts (Bureau of Labor Statistics, 2005, 2004a, 2004b), increased globalization, rapid rate of technological advances (e.g., Friedman, 2005; Kanter, 2001), changes in the psychological employment contract (Cappelli, 2000; Reitman \& Schneer, 2003; Rousseau, 1989; Rousseau \& Wade-Benzoni, 1995), and the greater mobility of the labor force (e.g., changing jobs every 4.5 years; Arthur \& Rousseau, 1996), studying career regrets is increasingly important because individuals in today's turbulent career landscape may face more career choices, and thus may have more opportunities to experience regret, than previous generations of workers. Comprehending what type of career regrets individuals experience may permit researchers to better understand how individuals enact their careers, provide greater insights into evolving career theory (e.g., boundaryless, protean career concepts; Arthur, Khapova \& Wilderom, 2005; Arthur \& Rousseau, 1996; Briscoe, Hall, \& DeMuth, 2006; Hall, 1996 \& 2004), and offer insights to individuals who are trying to navigate an ever more complex work environment.

Why has there been little empirical examination of career regrets? Research on careers has tended to focus on upward movement within one or two firms (e.g., Super, 1957) and how to succeed in such a work environment (Eddleston, Baldridge \& Veiga, 2004). Past research has focused on repeatedly winning rounds in the career tournament (see $\mathrm{Ng}$, Eby, Sorensen, \& Feldman, 2005, for a review; Rosenbaum, 1979) and how certain factors, like having a mentor (Kram, 1985; Forret \& de Janasz, 2005) can enhance career outcomes. Although workers in 
Western countries may change jobs much more often than in the past (Arthur \& Rousseau, 1996) and increasingly seek intrinsic sources of satisfaction as well as extrinsic rewards (Hall, 1996, 2002), most research still focuses on the linear career model and defines success in terms of rate of promotions and salary increases (Arthur et al., 2005; Feldman, 1989). But not all workers are winners in today's labor market. Given the widespread lay-offs and under-employment of white collar professionals, it is important that research examines not only the lessons on how to succeed but also the lessons that may be learned from failures, and the regrets individuals may have about their careers.

The purpose of this paper is to explore the under-researched topic of career regrets against the backdrop of the continually shifting, contemporary career landscape. Conceptualizing how individuals make sense of their own careers - the successes and the failures, with their associated regrets about career choices and events - is more imperative than ever given that careers are no longer viewed as bounded by a single organization, industry, profession, or even country (Arthur \& Rousseau, 1996) nor are they solely characterized by upward advancement (Cappelli, 2000) or extrinsic rewards (Hall, 1996; Heslin, 2005). Instead, careers are viewed with no connection to a specific organization (or industry, profession or country) as illustrated by Hall's (2002, p. 12) definition of contemporary careers as "the individually perceived sequence of attitudes and behaviors associated with work-related experiences and activities over the span of the person's life." Individuals, especially those without a long term relationship with an organization, are increasingly responsible for their own career management (Hall, 1996; Mallon \& Walton, 2005) and may particularly benefit from insights about how to avoid career regrets when possible, or learn from the regrets experienced by others.

This article begins by reviewing past research on regrets and detailing specific 
hypotheses on the relationship between career strategies, career events, and career regrets. Next, research methods and analysis are detailed. Finally, results are discussed and implications for scholarship and practice presented.

\section{Career Regrets}

The psychological literature defines regrets as remorse about outcomes different from the ones hoped for (Barron, 2000). Regretful thinking often occurs in response to unfavorable outcomes or unmet expectations (Zeelenberg et al., 1998). The idea of reducing the potential for regrets, and the subsequent negative outcomes (e.g., dysfunctional turnover, job dissatisfaction), is the underlying foundation of a number of organizational processes including the use of realistic job previews during the organizational entry process (Blenkinsopp \& Zdunczyk, 2005; Wanous, 1992) and training to reduce the culture shock that often leads expatriate managers to prematurely terminate international job assignments (e.g., Black \& Gregersen, 1999).

Scholars have also recently begun to study those who may be more prone to regrets, such as the case of research on entrepreneurial regrets (Markman, Balkin, \& Baron, 2002; Markman, Baron, \& Balkin, 2005). Because the process of founding a business is replete with obstacles and setbacks, entrepreneurs may experience substantially more (or different) regrets than others. For example, Markman et al. (2005) found that entrepreneurs regret decisions about lost business opportunities more than decisions about career and educational possibilities, whereas their nonentrepreneurial counterparts expressed greater regrets over career and educational decisions.

Although models of adult development suggest that individuals, especially at midlife, are more prone to regrets over lack of achievements (see Crocitto, 2006, for a review), even individuals who experience exceptional accomplishments are not immune to regrets. Research has reported that Olympic athletes who win a bronze medal are frequently more excited than 
silver medal winners. The silver medal winners may experience more regretful thoughts about being so close to winning the gold while the bronze medal winners are happy just to be included in the winner's circle (Medvec, Madley, \& Gilovich, 1995).

Because we could find no published studies specifically on career regrets, our approach to understanding regrets within the context of careers is exploratory and focuses on two major types of regrets. The first type we examined is those regrets associated with career behaviors aimed at enhancing objective success. Given the long-held view of careers as a linear progression up the corporate ladder where success is rewarded with additional pay and promotional opportunities (e.g., Super, 1957), people may regret not taking action to enhance their career advancement and associated extrinsic outcomes. For example, being savvy to corporate politics, choosing allies carefully, networking, and developing stronger managerial skills are behaviors that individuals may wish they had engaged in more effectively that could have increased the possibility of future promotions and other outcomes.

The second type we examined is those regrets associated with behaviors aimed at enhancing subjective success. More recent models of careers suggest that individuals are redefining career success beyond extrinsic outcomes (Briscoe et al., 2006; Hall \& Chandler, 2005). People may regret not engaging in behaviors that would have provided enhanced personal or spiritual fulfillment such as going back to school and pursuing a new career path, leaving the corporate world and becoming self-employed, or creating a better work/family balance for themselves (Friedman \& Greenhaus, 2000; Hall, 1996; Heslin, 2005; Powell \& Mainiero, 1992).

To explore how individuals experience career regrets, we examined the relationship between two career strategies (i.e., pursuing career opportunities at different firms and changing jobs for family reasons) and two career events (i.e., being plateaued and being laid off) with both 
objective and subjective career regrets.

First, we investigate the career strategy of pursuing career opportunities at different firms in one's industry. In the past, certain industries were characterized by high mobility and turnover. Saxenian (1996), for example, provided a case study of how social networks supported the high rates of job mobility and continuous learning among professionals in Silicon Valley. She detailed how the region's open labor markets made job hopping the norm and encouraged loyalty based on professional relationships rather than organizational membership. Similarly, Jones (1996), using case studies and prior literature, examined project networks in the film industry. She described how individuals with portable skills moved from one movie project to another, gaining skills and building a reputation that would ensure their continued employability. But such movement is not limited to those in Silicon Valley or in the film industry. In an internet-defined world, the rate of movement across firms has increased and fewer individuals have implicit "cradle to grave" psychological contracts with their employers (e.g., Arthur \& Rousseau, 1996; Mainiero \& Sullivan, 2005). With the advent of Monster.com and other job bank networks, available options are now more easily known to a larger populace. Moreover, individuals may more readily perceive a boundaryless future and alternative career opportunities. For instance, Sullivan and Arthur (2006) discuss the case of Karl, a chef, who worked in many different restaurants, gaining the expertise and self-confidence that enabled him to open his own restaurant. Karl not only had the physical mobility that is often associated with a boundaryless career (i.e., working for many different firms) but he also sustained high expectations of his own employability (i.e., psychological mobility). The freedom to move and to create one's own mobility may lead to lesser regrets about being stuck or entrenched in the same job on a continuous basis. 
Having high physical mobility may also positively impact feelings of psychological mobility, thereby reducing regrets. Sullivan and Arthur (2006) present the case of Eileen, a selfemployed management consultant, which helps illustrate the connection between physical and psychological mobility. Eileen seeks employment with a variety of firms to gain different experiences. As she gains these experiences, her self-assurance grows enabling her to perceive more opportunities for other types of work (e.g., line management positions). Thus, those who are more physical mobile and pursue career goals at different firms, may come to realize that their skills are highly transferable and that they have many alternative career paths open to them. Therefore, we posit:

Hypothesis 1: Those individuals who pursue career goals at different firms will experience fewer objective and subjective career regrets than those who are less mobile.

Next, we examine the career strategy of changing jobs or careers to better respond to family needs and its relationship to career regrets. The issue of family balance often is illuminated in discussions about career behaviors and choices. Family decisions about following a spouse to a new work location, staying home to rear young children, or allowing one spouse to take a work interruption frequently pivot on family issues (Eby et al., 2005; Friedman \& Greenhaus, 2000; Parasuraman \& Greenhaus, 1997). Research has found that individuals who interrupt the traditional linear career experience lower levels of career outcomes (Schneer \& Reitman, 1997). For instance, 70\% of the participants in Wise and Millward's (2005) qualitative study of voluntary career changers reported a substantial salary drop.

Individuals, especially those who value security, power, and position, may be especially concerned about making changes due to family demands. They may believe that making a change because of family circumstances will later cause them to struggle to catch up with others 
their own age (Wise \& Millward, 2005). O'Neil and Bilimoria (2005), for instance, examined the effect of societal context on women's career development, reporting that women taking career interruptions often found the experience of returning to the workforce to be frustrating. Some of the women were disheartened to find that important unpaid experiences, such as volunteer work in which they raised large sums of money for charity, were not considered by employers to be “real experience” (see O’Neil \& Bilimoria, 2005, p. 175). Because work is a major source of identification for many individuals (e.g., Arvey, Harpaz, \& Liao, 2004) with people often defining themselves by what they do (e.g., I'm a banker, teacher, accountant), individuals who make job or career adjustments to meet family needs may feel a loss of identity if they take timeout from their careers, are underemployed, or take on a less challenging job in order to spend more time caring for children or elderly relatives. Therefore we propose:

Hypothesis 2: Individuals who make a job or career change due to family needs will experience greater objective and subjective career regrets than those who don't make such changes.

In addition to the two career strategies, we also examined the two career events of being plateaued and being laid-off. The literature on derailment and organizational plateauing (e.g., McCall, Lombardo, \& McCauley, 1988; McCall, Lombardo, \& Morrison, 1988) discusses how individuals can feel trapped by societal definitions of career success, with the explicit notion that "up is the only way" (Kaye, 2002). In her research on derailment, Kovach (1989) explores this widespread assumption in U.S. corporate culture and how this assumption can result in large numbers of individuals feeling like losers, even those who had previously been successful executives. Shipper and Dillard (2000) further found that individuals blame themselves for not taking the necessary actions to prevent derailment. Individuals who have leveled off often engage in retrospective thinking as to what could have been, and what they should have done 
differently. These individuals believed that if one worked hard enough, then rewards would have followed (Levinson, 1978). They may regret not engaging in potentially career enhancing behaviors, such as networking and engaging in political behavior, which may have resulted in greater advancement and extrinsic outcomes. Likewise, individuals who plateaued may regret not taking more chances, forging a new career path or devoting more time to nonwork concerns. Individuals may imagine how much better their lives would have been if they had investigated an alternative career path (e.g., started their own business). Therefore, we hypothesize:

Hypothesis 3: Individuals who report they have leveled off in their careers will experience greater objective and subjective career regrets than those who have not leveled off.

Like individuals who leveled off in their careers, individuals who have been laid off from an organization are more likely to have career regrets. These individuals bought into the psychological contract in which firms offered job security in exchange for worker loyalty. However, the psychological contract has changed and even employers known for their promise of life-long employment engaged in downsizing and rightsizing (Rousseau \& Wade-Benzoni, 1995). Research on the effects of layoffs on both those terminated and those who remained report many negative outcomes (Brockner et al., 1992; Leana \& Feldman, 1991, 1994). Besides the loss of income and status associated with losing one's job, Feldman and Leana (2000) found that downsized managers have lower trust and are more cynical about their careers. Having misplaced their trust in former employers, the negative attitudes of laid off workers spillover and adversely impact their perceptions of their careers. Individuals who were laid off may feel betrayed by their organizations and may regret not engaging in behaviors that may have prevented their dismissal; they may also regret the time invested in jobs that "died" and may wish they had devoted more time elsewhere (e.g., family). Therefore we hypothesize: 
Hypothesis 4: Individuals who report they were laid off will experience greater objective and subjective career regrets than those who were not laid off.

\section{METHOD}

\section{Survey Administration and Sample}

Our survey was posted on a website of one of the largest established marketing research panels in the U.S. This firm is able to employ a variety of statistics and structural methods to ensure varied sample composition and sufficient response rates, thereby increasing the likelihood of obtaining a representative sample. The firm draws on approximately 10,000 individuals of various ages, races, backgrounds, industries, and job titles. These individuals have agreed to participate in research conducted by the firm for a fee, with respondents required to participate in two surveys per month to maintain an active status. By participating in surveys, respondents' logins are also entered into a drawing for a chance to win a $\$ 100.00$ cash prize. Respondents are not required to purchase products for market research purposes. Typically, surveys are made available on the website until percentages and numbers as requested by the researcher are obtained; we made no requests so as to avoid biasing the sample in any way. Moreover, the posted survey contained only our questions. The firm reported that the response rate for the survey was $22 \%$, which they considered very good given typical response rates.

After removing those who were self-employed $(n=167)$, our sample size was 1480 and was almost evenly split between men $(n=764)$ and women $(n=716)$. Respondents reported their ethnic status as Caucasian (88\%), African-American (4\%), Asian (3\%), Hispanic or Latin American (2\%), Native American (1\%), and Other/Prefer Not to Say (2\%). Because of our large sample size, we were able to explore whether career regrets might differ at various ages. Following from the developmental career theories (see Sullivan \& Crocitto, in press, for a 
review), four age groups were employed for the purposes of this study (34 and younger, $n=455$; $35-44, n=449 ; 45-54, n=418 ; 55$ and older, $n=158)$. The educational level of the respondents varied: $14 \%$ were high school graduates; $65 \%$ attended some college or graduated from college; and $21 \%$ had completed some graduate work or held a postgraduate degree. Respondents worked in a wide variety of industries, ranging from education (13\%), healthcare (10\%), government (11\%), retail (9\%), finance/banking (5\%), computers $(4 \%)$, telecommunications (3\%), engineering/architecture (3\%), and others (42\%). The respondents worked an average of 42 hours per week, with 37\% $(n=549)$ describing their careers as having leveled off, and $28 \%(n=412)$ having experienced being laid off. Forty-six percent of the respondents reported having children in the household, and $11 \%$ reported having eldercare responsibilities.

\section{Dependent Variables}

Because no prior empirical research had been completed on career regrets, we developed a twelve-item scale to measure objective and subjective career regrets based on a review of the careers literature. Using a Likert scale ranging from strongly disagree $=1$ to strongly agree $=5$, respondents indicated their level of agreement with the twelve items listed in Table 1. To examine whether the two types of career regrets were distinct constructs, a principal components factor analysis with a varimax rotation was performed on the scale. Examination of the scree plot and the eigenvalue-greater-than-1 criteria suggested that two factors be retained. The factor analysis results are shown in Table 1 . Next, scales were created by calculating the means of the items that (a) loaded .40 or greater on that factor, (b) did not load .40 or greater on any other factor, and (c) loaded on one factor at least .10 higher than on any other factor. Such procedures have been used in other research on careers (e.g., Forret \& Dougherty, 2001). 
Factor 1 was labeled objective career regrets. It is comprised of five items (i.e., items 1 , 2, 3, 8, and 9 in Table 1) and measures the extent to which respondents wished they had behaved differently in order to advance up the corporate ladder and gain more extrinsic rewards (e.g., built a stronger network, paid attention to corporate signals, developed stronger managerial skills). The coefficient alpha for this scale was .81. Factor 2 was labeled subjective career regrets. It is comprised of seven items (i.e., items $4,5,6,7,10,11$, and 12 in Table 1) and measures the extent to which respondents wished they had taken more action that would have resulted in enhanced personal satisfaction and fulfillment (e.g., pursued more creative work, went back to school, focused more on family). The coefficient alpha for this scale is .77 .

\section{Independent Variables}

Worked at different firms was measured using a five point Likert scale $(1=$ does not describe my career; 5 = directly describes my career) where respondents were asked to reply to the item, "I have pursued my career goals at several different firms in my industry." Using the same five point Likert scale, changed job for family needs was assessed by respondents' answers to the item, "Family needs necessitated that I change jobs/careers so that I could achieve a better balance for my work and family." We focused on the respondents' perceptions of whether they had leveled off in their careers rather than imposing our own biases (e.g., counting number of promotions per every five years). Respondents indicated whether their careers had leveled off $(0=$ yes, $1=$ no $)$. Lastly, respondents indicated whether they had ever been laid off $(0$ $=$ yes, $1=$ no).

\section{Control Variables}

Control variables for the study were grouped into two categories: personal background variables and human capital variables. The personal background variables consisted of gender (1 
$=$ male, $2=$ female $)$, children in the household $(1=$ yes, $2=$ no), eldercare responsibilities $(1=$ yes, $2=$ no), and household income $(1=$ less than $\$ 20,000,2=\$ 20,000-29,000,3=\$ 30,000$ $39,000,4=\$ 40,000-49,000,5=\$ 50,000-59,000,6=\$ 60,000-74,000,7=\$ 75,000-99,000$, $8=\$ 100,000-199,000$, and $9=\$ 200,000$ and above). The human capital variables measured were education (on a scale from $1=$ some high school to $7=$ post graduate degree), and the number of hours respondents worked in a typical week. Both categories of control variables were selected for inclusion in the study as they provide insight as to the resources, constraints, and opportunities that might influence people's careers and are consistent with past research.

\section{RESULTS}

The correlations, means, and standard deviations of the study variables are shown in Table 2. Pursuing career goals by working at different firms was significantly related to objective career regrets only, but in a direction opposite to that hypothesized. The more individuals moved to different firms, the more objective regrets they reported. Family needs necessitating a job/career change was significantly related to subjective, but not objective, career regrets in the anticipated direction. Those who made changes due to family needs reported greater subjective career regrets. Lastly, the two career events (leveled off, being laid off) were both significantly associated with objective and subjective career regrets in the hypothesized direction.

Hierarchical multiple regression analyses were performed, with the personal background control variables entered as the first block, followed by the human capital control variables in the second block, and the independent variables in the third block. Using the developmental career stage models as a guide, regressions predicting objective and subjective career regrets were computed for four separate age groupings: ages 34 and younger, ages 35 - 44, ages 45 - 54, and ages 55 and older. The results of these regression analyses are shown in Table 3. 
Hypothesis 1, which stated that those individuals who pursued career goals at different firms should experience fewer objective and subjective career regrets was partially supported. For individuals who were 34 and younger, those who had not pursued career goals at different firms had significantly more subjective regrets; they perhaps regretted not taking advantage of opportunities to do more exploring in different organizations or to pursue alternative options such as starting their own businesses, going back to school, or staying at home - while still young and without the responsibilities that often increase with age. Respondents in the 55 and older age category who didn't pursue career goals at different firms also reported significantly more objective and subjective regrets. This may suggest that individuals who were loyal to their organizations and did not engage in frequent organizational moves believed they had limited their career progress in their industry, and that they should have gained a wider array of experiences.

Similarly, Hypothesis 2, which examined whether those who made job or career changes for family needs would have greater objective and subjective regrets, was partially supported. In three of the four age groupings, respondents who reported that family needs necessitated a job/career change were significantly more likely to experience subjective regrets. In contrast, only for respondents in the 55 and older category was there a significant finding for objective career regrets. These individuals may believe they would have advanced further up the ladder if not for family obligations.

Hypothesis 3, which focused on leveling off, was partially supported. Leveling off in one's career was associated with significantly greater objective and subjective regrets in the 35 44 age category, and with significantly greater subjective regrets in the 45 - 54 age category. It may be that respondents in these age groups are entering into midlife or experiencing a midlife 
crisis. According to developmental career models (e.g., Levinson, 1978), they may have begun to realize that their careers are not as upwardly mobile as they would have liked. They may also be questioning "the road not taken" and whether alternative career choices would have helped them avoid plateauing.

Hypothesis 4, which examined the impact of being laid off, received the strongest support. Individuals who reported they had been laid off experienced significantly greater objective regrets across all four age groups, and significantly greater subjective regrets across two of the age groups. Although layoffs have become commonplace among white collar workers, it appears that individuals still feel a sense of remorse over what they could have done (e.g., made more allies, developed better networks) that may have prevented their dismissal or, for those in the 35 - 44 and 55 and older age groups, regret not spending more time with their families or pursuing alternative career paths (e.g., returning to school).

The control variables produced some interesting statistically significant results. For the youngest age group, having eldercare responsibilities was associated with more objective and subjective regrets. Those caring for elderly relatives may be less able to focus on doing the types of behaviors needed to move ahead in their organizations, and may believe embarking on an alternate career path would have made their responsibilities easier to manage. Having a lower household income was also related to more objective regrets for this age group. As these individuals are early in their careers, this result is not surprising; they may feel a lower income is a sign that their careers are not "on track." Our results also showed that men in the 45 - 54 age category were more likely than women to experience objective career regrets. It may be that this is the age range where men realize the limits to their advancement potential and regret not being stronger corporate players. Turning to the human capital variables, the findings for education 
were varied. Education was negatively related with subjective regrets in the 35 - 44 and 45 - 54 age categories, and positively related with objective regrets in the 55 and older group. Those with less education may have experienced blocked opportunities and feel they should have chosen a different path, whereas older respondents with more education may feel they should have progressed farther up the ladder. Finally, number of hours worked produced more regrets in the oldest age category (55 and older), suggesting that when individuals review their work histories later in life, they may realize that working long hours does not necessarily lead to advancement and may come to understand the family and personal experiences that were sacrificed due to their work schedules.

\section{DISCUSSION}

Our research examines the types of regrets that individuals experience during their careers. We explored two major types of regrets - regrets about not utilizing career strategies (e.g., building a stronger network, paying attention to corporate signals) more effectively that would have helped individuals achieve greater objective career success, and regrets about not pursuing alternative career paths (e.g., pursuing more meaningful work, focusing more on family) that would have lead to greater subjective career success. We investigated how pursuing career goals at several different firms, changing jobs/careers to achieve a better work/family balance, plateauing in one's career, and being laid off are related to the experience of both objective and subjective career regrets.

Our results show that certain events and career strategies were linked to more regretful thinking than others. Most notably, those who were laid off were more likely to have objective career regrets, and also, to a lesser extent, subjective regrets. This is consistent with the downsizing literature that illustrates the negative effects of job loss (e.g., Leana \& Feldman, 
1994). Individuals may engage in self-blame as they reflect upon actions they could have taken to enhance their job security. Additionally, they may feel their efforts to help their organization achieve success were wasted, and their time and energies could have been better spent elsewhere (e.g., pursuing self-employment options or more meaningful work).

We also found differences based on age. For those individuals who reported leveling off in their careers, the results were most pronounced in the 35 - 44 age category; individuals reported both significant objective and subjective regrets. According to the careers literature, this would be the age range when workers would realize their promotability may not be as fast as desired ( see Sullivan \& Crocitto, 2007 for a review).. Therefore, we speculate that there is a clash with the reality of the corporate pyramid that produces greater regrets in this age group; when these individuals level off, they may examine various alternative career options, choices, and paths to determine if the proverbial road not taken might be better than the one they actually pursued. Perhaps what is more surprising is that those in two of the other age groups (34 and younger, 55 and older) who had leveled off did not experience significant regrets. This suggests that those early or late in their careers who perceive themselves as plateaued do not view it as negatively as would be suggested by the literature that focuses on upward movement as a measure of career success (Ng et al., 2005; Rosenbaum, 1979). Those early in their careers may believe that the plateau is temporary or that they will move beyond it as they gain more experience or pursue different career options. Or, as some of the studies of generational differences suggests (e.g., Catalyst, 2001; Smola \& Sutton, 2002), these younger individuals may care less about upward movement than previous generations. Similarly, those in the 55 and older age group may have come to terms with being plateaued or may be focusing on matters of creating greater authenticity in their lives rather than focusing on career advancement (Mainiero 
\& Sullivan, 2006).

In addition, consistent relationships were shown between family needs necessitating job/career changes and subjective career regrets (with the exception of the 45 - 54 age category). One interpretation for this finding is that organizations have not made sufficient inroads for employees to satisfactorily balance work and family needs (Burud \& Tumolo, 2004). As such, individuals expressing subjective regrets may desire alternatives such as pursuing a new career path or self-employment which may enhance flexibility and give them more control over how they manage work and nonwork demands. Research on female entrepreneurs, for instance, has found that many women leave corporations in order to build companies that permit them to nurture their family while experiencing career challenge (Moore, 2002) or to create companies that promote better work/life balance (Mainiero \& Sullivan, 2006). Although these individuals made job changes for the sake of their families, they may wish they had taken a career interruption sooner, stayed out of the workforce longer, or chosen another alternative means, such as entrepreneurship, to better benefit their families.

Finally, most notably in the 55 and older age category, those who did not pursue career goals at different firms were more likely to experience both objective and subjective regrets. Spending the vast majority of one's career at one or two organizations is consistent with the traditional career model. However, it appears that as these individuals reflect back on their careers, they may be wondering how far they could have risen had they pursued their career goals at different firms, struck out on their own, or taken a different career path. Or they may be reflecting back and lamenting the time and effort devoted to their careers, wishing they had instead taken a career path that permitted more time for family and other pursuits.

Despite criticisms of the developmental career stage models (e.g., Sullivan, 1999), the 
experience and reporting of regrets did vary for the different age groups utilized in our study. Regrets were more pronounced particularly in the 35 - 44 age group and the 55 and older age group. The regrets in the 35 - 44 age group may be the result of mid-life evaluations (Levinson, 1978; Sullivan \& Crocitto, 2007). It is intriguing that those age 55 and older (except in regards to plateauing) reported both objective and subjective regrets. Perhaps as individuals look back over their life span - and have the advantage of 20/20 hindsight - there are more forks in the road (i.e., alternative opportunities) that were not taken (or possibly not even recognized as opportunities at the time they occurred), that may lead individuals to experience regretful thinking as they contemplate their life experiences. This is in line with developmental career theories, beginning with Erikson's model (1968) and his integrity versus despair in advanced middle age, as well as other life span models and research (Crocitto, 2006; Levinson, 1978). The age-based theories of career progression operate on the assumption that regrets about lost opportunities most likely build over the course of a lifetime. As individuals age, their career regrets may naturally grow. For instance, individuals may initially begin their careers with a sense of optimism and a focus on establishment in their careers. Later, as they advance in age and their personal lives become more complicated by health issues, marriage(s), financial concerns, children, and eldercare demands, the values and priorities of individuals are likely to change. As described by the developmental career models, at the end of the career/life cycle, individuals may become even more reflective and gain a clearer retrospective vision of how their careers played out and the missed opportunities along the way. Further study about how such reflective thinking throughout the life cycle may impact career decisions (e.g., making career choices today to avoid potential regrets tomorrow) should be undertaken.

It is also interesting to note that the correlation analysis supports past research on 
work/family demands. Analysis of the correlations showed that men worked significantly more hours and were more likely to pursue career goals at different firms. Women, on the other hand, were significantly more likely to report that family needs necessitated a job change. The literature on family balance shows that it is most often the woman who becomes the trailing spouse (e.g., Bielby \& Bielby, 1992) and that women often take a career interruption to care for

family and children (Schneer \& Reitman, 1997). Because of the extensive media attention on high profile women leaving plum jobs to pursue part-time work or take a career interruption (see Mainiero \& Sullivan, 2005, for a theory-based empirical analysis of what the media calls the “opt-out revolution"), these findings suggest that further research is needed to more deeply probe the potential differences in regrets of women and men who make the decision to stay in the workforce or to opt-out of corporations for other career or family pursuits.

\section{Limitations, Implications, and Directions for Future Research}

Although this study suggests a number of interesting lines for future research, several limitations must be noted when considering its findings. First, there have been some questions about the generalizability of Internet-based surveys (Birnbaum, 2004; Couper, 2000). We had strong reasons, however, for choosing this technology. One reason for our use of this emerging research technology is the ability to access a large and varied survey population. Our survey was listed on the website of one of the largest established marketing research panels in the U.S., and this firm is able to employ a variety of methods to ensure varied sample composition and sufficient response rates, thereby increasing the likelihood of obtaining a representative sample. Another reason for our use of this technology is that recent research has found that web-based samples compare favorably to traditional survey methods. Although Internet samples may not be fully representative of the population at large, they are usually more diverse than samples 
published in highly selective psychology journals utilizing student populations (Gosling, Vazire, Srivastava, \& John, 2004). For example, Gosling and associates (2004) reported that Internet samples were more representative than traditional pencil-and-paper samples with respect to gender, socioeconomic status, geographic location, and age, and were about as representative as traditional samples with regard to race. Other researchers (e.g., Berrens et al., 2003, 2004) have found Internet samples to be comparable to large-scale telephone samples in terms of representing the general population.

Second, like most of the research in our field, our study was cross-sectional. Because data were collected at one point in time no statements about causality can be made. Furthermore, while career regrets differed in the various age categories, the data was collected from different respondents. Future longitudinal studies concerning the development of career regrets over time would help us better comprehend how career regrets might vary throughout the life span and affect career choices. Future research should also consider other variables that were not included in this study but may explain additional variance. For instance, career satisfaction was not measured. It may be that those who engaged in regretful thinking were less satisfied with their career paths (or their lives in general). Likewise, there may be other factors such as personality traits, cultural differences, whether individuals evaluate their regrets in relation to other-referent or self-referent criteria, and how salient different career outcomes are to individuals that may influence the degree to which individuals regret the past (see Heslin, 2005). Also, in the spirit of enhancing research through multiple methods, we recommend that qualitative studies be completed. Such qualitative studies may provide a richer understanding of career regrets across the lifespan and be the basis for further theory development. 
Third, because one survey was used to collect the data, our findings may be subject to common method variance. However, the presence of demographic and otherwise verifiable information (e.g., getting laid off) makes common method variance less of a concern (Crampton \& Wagner, 1994; Podsakoff \& Organ, 1986). To test for common method variance, we conducted Harman's one-factor test by including the study variables in an unrotated factor analysis (Podsakoff \& Organ, 1986). The results broke into several factors, providing some evidence against method variance problems in the data.

Despite these potential limitations, this study makes several contributions to the literature on careers. First, while having regrets about one's career is a premise of many of the established developmental career theories (Sullivan \& Crocitto, 2007), to our knowledge this is the first study to empirically explore career regrets as a variable worthy of consideration. Future studies of how retirees reflect back upon their careers and perceive how career choices lead to good or bad outcomes may provide further insights into how and why career regrets develop and test commonly held beliefs about careers regrets (e.g., greater regrets for actions not taken, than for actions taken that ended in failure).

A second contribution of this study is it provides additional insights into age-based changes in development over time. The majority of the significant findings were in the $35-44$ age category and the 55 and older age category. It may be that those in the 35 - 44 age range feel caught in a dilemma. While they have invested a great deal in their careers, they may still believe they are young enough to make significant changes to their career paths. We were not surprised by the overall findings for the oldest group. These results support the theories of career development that suggest that age and wisdom, as well as reflective thinking, are related.

A third contribution of this study is that unlike much of the literature, it focuses on career 
regrets rather than career success. Research on traditional careers tends to focus on success and most of the writings on nontraditional careers (e.g., boundaryless, protean) have also emphasized the positive aspects of making career transitions such as the learning benefits derived by working for many different employers (Heslin, 2005; Sullivan, 1999). For instance, nontraditional career theories tend to assume that workers can easily transition from job to job, organization to organization and the like; in other words, these theories suggest that individuals are what Atkinson (1984) calls “plug-in workers.” Individuals, however, must not only have transferable knowledge in their field in order to be hired by these different employers but also must rapidly gain an understanding of the setting in which they work (Blenkinsopp \& Zdunczyk, 2005). Our emphasis on career regrets is thus a departure from past research examining success factors.

A fourth contribution of this study is that differences between objective and subjective career regrets were recognized and tested; this is an important consideration given that the career paths of workers have become disjointed and more laterally driven than ever before. Despite increased conceptualization of nontraditional careers, research has still tended to focus on traditional careers (Arthur et al., 2005). By examining career regrets, we hoped to shed further light on the complexities of contemporary careers. Although this study focused on a limited number of career strategies and events, we suggest that future research consider the possible negative aspects of nontraditional careers (e.g., obstacles to remaining employable, stress of repeatedly seeking out project work or adapting to new employers) and examine the potential for career regrets related to different types of career transitions, strategies, and events. For instance, while many nontraditional career theories assume that people have equal chances to pursue alternative career paths, in reality this is not always the case. Societal norms and expectations may restrict women's occupational, educational and job choices while other factors such as 
discrimination, sexual harassment and work policies may limit their advancement opportunities, resulting in women having less physical mobility than men. In contrast, men may perceive fewer career possibilities than women (i.e., have less psychological mobility) because societal norms may put them into mental straitjackets, requiring them to conform to traditional work and family (i.e., breadwinner) roles (Mainiero \& Sullivan, 2006; Sullivan \& Arthur, 2006). Future research should examine obstacles that may deter career strategies (e.g., working for many different employers) and how other factors, such as cultural norms and individual differences, may also limit the extent to which people can enact nontraditional careers. It is our hope that this study of career regrets encourages scholars to take a closer look at assumptions about the ease of career transitions, factors that could affect the transition process, and how regrets about past career strategies and events may influence future career choices. Additionally, we hope that future research also examines how organizational actions (or lack of response) and other players in an individual's career, (e.g., managers, colleagues and mentors), may positively or negatively affect the regrets experienced.

Fifth, these findings may offer some insights to help individuals navigate their careers and make choices that they will be less likely to regret. Moreover, the regrets individuals are most likely to experience at different points in the lifespan may provide career counselors and coaches with a better understanding of how careers unfold over time, and how different generations may hold various perspectives on the same career event (e.g., leveling off). Such knowledge may also help provide more effective career counseling for those individuals who have experienced career missteps.

In conclusion, the study of career regrets represents a productive and fruitful arena for future research on the subject of careers. The regrets individuals have may influence their career 
Career Strategies and Career Regrets 26

behaviors and transition decisions, resulting in different approaches to their work and their lives.

Longitudinal studies of career regrets may help us to understand why the proverbial "road not

taken" could serve as an impetus for life and career decisions that individuals must reconcile

over time.

\section{References}

Atkinson, J. (1984). Managing strategies for flexible organizations. Personnel Management, 16(8), 28-31.

Arthur, M. B., Khapova, S. N., \& Wilderom, C. P. M. (2005). Career success in a boundaryless career world. Journal of Organizational Behavior, 26(2), 177-202.

Arthur, M. B. \& Rousseau, D. M. (1996). The boundaryless career. New York: Oxford University Press.

Arvey, R. D., Harpaz, I., \& Liao, H. (2004). Work centrality and post-award work behavior of lottery winners. Journal of Psychology, 138(5), 404-420.

Baron, R. A. (2000). Counterfactual thinking and venture formation: The potential effect of thinking about what might have been. Journal of Business Venturing, 15, 275-294.

Berrens, R. P., Bohara, A. K., Jenkins-Smith, H. C., Silva, C. L., \& Weimer, D. L. (2003). The advent of Internet surveys for political research: A comparison of telephone and Internet samples. Political Analysis, 11, 1-22.

Berrens, R. P., Bohara, A. K., Jenkins-Smith, H. C., Silva, C. L., \& Weimer, D. L. (2004). Telephone versus Internet samples for a national advisory referendum: Are the underlying stated preferences the same? Applied Economics Letters, 11, 173-176.

Bielby, W. T., \& Bielby, D. D. (1992). I will follow him: Family ties, gender role beliefs, and reluctance to relocate for a better job. American Journal of Sociology, 97(5), 1241-1267.

Birnbaum, M. H. (2004). Methodological and ethical issues in conducting social psychological research via the Internet. In C. Sansone, C. C. Morf, \& A. T. Painter (Eds.), Handbook of methods in social psychology (pp. 359-382). Thousand Oaks, CA: Sage.

Black, J. S., \& Gregersen, H. B. (1999). The right way to manage expats. Harvard Business Review, 77(2), 52-63.

Blenkinsopp, J., \& Zdunczyk, K. (2005). Making sense of mistakes in managerial careers. Career Development International, 10(5), 359-374.

Briscoe, J. P., Hall, D. T., \& DeMuth, R. L. F. (2006). Protean and boundaryless careers: An empirical exploration. Journal of Vocational Behavior, 69(1), 30-47.

Brockner, J., Grover, S., Reed, T., \& DeWitt, R. L. (1992). Layoffs, job insecurity, and survivors' work effort. Academy of Management Journal, 35, 413-425.

Bureau of Labor Statistics. (2005, May). Women in the labor force: A datebook. Washington, D.C.: United States Department of Labor Report 985.

Bureau of Labor Statistics. (2004a, April 20). Employment characteristics of families survey. USDL04-719, www.bls.gov.

Bureau of Labor Statistics. (2004b, May 24). Contingent and alternative employment arrangements. USDL 010153, www.bls.gov.

Burud, S., \& Tumolo, M. (2004). Leveraging the new human capital. Palo Alto: Davies-Black. 
Cappelli, P. (2000). The new deal at work. Boston, MA: Harvard Business School Press.

Catalyst. (2001, Dec 11). The next generation: Today's professionals, tomorrow's leaders. Catalystwomen.org Press Release.

Couper, M. P. (2000). Web surveys: A review of issues and approaches. Public Opinion Quarterly, 64, 464-494.

Crampton, S. \& Wagner, J. III. (1994). Percept-percept inflation in microorganizational research: An investigation of prevalence and effect. Journal of Applied Psychology, 79, 67-76.

Crocitto, M. (2006). Middle career stages. In J. Greenhaus (Ed.), The encyclopedia of careers. Thousand Oaks, CA: Sage.

Eby, L. T., Casper, W. J., Lockwood, A., Bordeaux, C., \& Brinley, A.(2005). Work and family research in IO/OB: Content analysis and review of the literature (1980-2002). Journal of Vocational Behavior, 66, 124-197.

Eddleston, K. A., Baldridge, D. C. \& Veiga, J. F. (2004). Toward modeling the predictors of managerial career success: Does gender matter? Journal of Managerial Psychology, 19(4), 360-385.

Erikson, E. H. (1968). Identity, youth and crisis. New York: Norton.

Feldman, D. C. (1989). Careers in organizations: Recent trends and future directions. Journal of Management, 15(2), 135-156.

Feldman, D. C., \& Leana, C. R. (2000). A study of reemployment challenges after downsizing. Organizational Dynamics, 29(1), 64-75.

Forret, M. \& de Janasz, S. (2005). Perceptions of an organization's culture for work and family: Do mentors make a difference? Career Development International, 10, 478-492.

Forret, M.\& Dougherty, T. D. (2001). Correlates of networking behavior for managerial and professional employees. Group \& Organization Management, 26(3), 283-311.

Friedman, S. D., \& Greenhaus, J. H. (2000). Work and family-allies or enemies? What happens when business professionals confront life choices. New York: Oxford University Press.

Friedman, T. (2005). The world is flat: A brief history of the 21 st century. New York: Farrar, Strauss, Giroux.

Gosling, S. D., Vazire, S., Srivastava, S., \& John, O. P. (2004). Should we trust web-based studies? A comparative analysis of six preconceptions about internet questionnaires. American Psychologist, 59, 93-104.

Hall, D. T. (1996). The career is dead - Long live the career. San Francisco: Jossey-Bass.

Hall, D. T. (2002). Careers in and out of organizations. Thousand Oaks, CA: Sage.

Hall, D. T. (2004). The protean career: A quarter-century journey. Journal of Vocational Behavior, 65, 1-13.

Hall, D. T., \& Chandler, D. E. (2005). Psychological success: When the career is a calling. Journal of Organizational Behavior, 26, 155-176.

Heslin, P. A. (2005). Conceptualizing and evaluating career success. Journal of Organizational Behavior, 26, 113-136.

Jones, C. (1996). Careers in project networks: The case of the film industry. In M. A. Arthur \& D. M. Rousseau (Eds.), The boundaryless career (pp. 58-75). New York: Oxford University.

Kanter, R. M. (2001). Evolve! Succeeding in the digital culture of tomorrow. Boston: Harvard Business School Press.

Kaye, B. (2002). Up is not the only way. Palo Alto, CA: Davies-Black.

Kram, K. E. (1985). Mentoring at work: Developmental relationships in organizational life.

Glenview, IL: Scott Foresman. 
Kovach, B. E. (1989). Successful derailment: What fast-trackers can learn while they're off the track. Organizational Dynamics, 18, 33-37.

Leana, C. R., \& Feldman, D. C. (1991). Gender differences in responses to unemployment. Journal of Vocational Behavior, 38, 65-77.

Leana, C. R., \& Feldman, D. C. (1994). The psychology of job loss. In G. R. Ferris (Ed.), Research in personnel and human resource management (pp. 271-302). Greenwich, CT: JAI.

Levinson, D. (1978). The seasons of a man's life. New York: Knopf.

Mainiero, L. A., \& Sullivan, S. E. (2006). The opt-out revolt: Why people are leaving companies to create kaleidoscope careers. Palo Alto, CA: Davies-Black.

Mainiero, L. A., \& Sullivan, S. E. (2005). Kaleidoscope careers: An alternative explanation for the opt-out revolution. Academy of Management Executive, 19(1), 106-123.

Mallon, M. \& Walton, S. (2005). Career and learning: The ins and the outs of it. Career Development International, 34(4), 468-487.

Markman, G. D., Balkin, D. B., \& Baron, R. A. (2002). Inventors and new venture formation: The effects of general self-efficacy and regretful thinking. Entrepreneurship Theory and Practice, Winter, 149-165.

Markman, G. D., Baron, R. A., \& Balkin, D. B. (2005). Are perseverance and self-efficacy costless? Assessing entrepreneurs' regretful thinking. Journal of Organizational Behavior, 26, 1-19.

McCall, M. W., \& Lombardo, M. M., \& McCauley, C. D. (1988). The dynamics of management derailment. Tech report 34. Greensboro, NC: Center for Creative Leadership.

McCall, M. W., Lombardo, M. M., \& Morrison, A. (1988). The lessons of experience: How successful executives develop on the job. New York: Lexington Books.

Medvec, V. H., Madley, S. F., \& Gilovich, T. (1995). When less is more: Counterfactual thinking and satisfaction among Olympic medalists. Journal of Personality and Social Psychology, 69, 603-610.

Moore, D. P. (2002). Careerpreneurs: Lessons from leading women entrepreneurs on building a career without boundaries. Palo Alto, CA: Davies-Black.

Ng, T. W. H., Eby, L. T., Sorensen, K. L., \& Feldman, D. C. (2005). Predictors of objective and subjective career success: A meta-analysis. Personnel Psychology, 58, 367-408.

O'Neil, D., \& Bilimoria, D. (2005). Women's career development phases: Idealism, endurance and reinvention. Career Development International, 10(3), 168-189.

Parasuraman, S., \& Greenhaus, J. H. (1997). Integrating work and family: Challenges and choices for a changing world. Westport, CT: Quorum Books.

Podsakoff, P. M., \& Organ, D. W. (1986). Self-reports in organizational research: Problems and prospects. Journal of Management, 12, 531-544.

Powell, G. N., \& Mainiero, L. A. (1992). Cross-currents in the river of time: Conceptualizing the complexities of women's careers. Journal of Management, 18, 215-237.

Reitman, F. \& Schneer, J. A. (2003). The promised path: A longitudinal study of managerial careers. Journal of Managerial Psychology, 18(1), 60-75.

Rosenbaum, J. (1979). Tournament mobility: Career patterns in a corporation. Administrative Science Quarterly, 24(6), 220-241.

Rousseau, D. M. (1989). Psychological and implied contracts in organizations. Employee Responsibility and Rights Journal, 2(2), 121-139.

Rousseau, D. \& Wade-Benzoni, K. (1995).Changing individual-organization attachments. In A. Howard (Ed.), Changing nature of work (pp. 290-321). San Francisco: Jossey-Bass. 
Saxenian, A. (1996). Beyond boundaries: Open labor markets and learning in Silicon Valley. In M. B. Arthur \& D. M. Rousseau (Eds.), The boundaryless career (pp. 23-39). New York: Oxford University Press.

Schneer, J. A., \& Reitman, F. (1997). The interrupted managerial career path: A longitudinal study of MBAs. Journal of Vocational Behavior, 51 (3), 411-434.

Shipper, F., \& Dillard, J. E. (2000). A study of impending derailment and recovery of middle managers across career stages. Human Resource Management, 39, 331-345.

Smola, K. W., \& Sutton, C. D. (2002). Generational differences: Revisiting generational work values for the new millennium. Journal of Organizational Behavior, 23, 363-382.

Sullivan, S. E. (1999). The changing nature of careers: A review and research agenda. Journal of Management, 25, 457-484.

Sullivan, S. \& Arthur, M. (2006). The evolution of the boundaryless career concept: Examining physical and psychological mobility. Journal of Vocational Behavior, 69(1), 19-29.

Sullivan, S. E., \& Crocitto, M. (2007). Developmental career theories. In M. Peiperl \& H. Gunz (Eds.), Handbook of career studies. Thousand Oaks, CA: Sage.

Super, D. (1957). Psychology of careers. New York: Harper \& Brothers.

Wanous, J. P. (1992). Organizational entry: Recruitment, selection, orientation and socialization of newcomers. Reading, MA: Addison-Wesley.

Wise, A. \& Millward, L. (2005). The experiences of voluntary career change in 30-somethings and implications for guidance. Career Development International, 10(5), 400-417.

Zeelenberg, M., van Dijk, W. W., Der Pligt, J. V., Manstead, A. S., Empelen, P. V., Dimitri, R., \& Pepihn, V. (1998). Emotional reactions to the outcomes of decisions: The role of counterfactual thought in the experience of regret and disappointment. Organizational Behavior and Human Decision Processes, 75(2), 117-141. 


\begin{tabular}{lll}
\hline Item & $\begin{array}{l}\text { Objective } \\
\text { Regrets }\end{array}$ & $\begin{array}{l}\text { Subjective } \\
\text { Regrets }\end{array}$ \\
\hline
\end{tabular}

1. I wish I had been more successful at networking in general, as I have lost many career opportunities due to my inability to build a strong network.

2. I wish I had been more of a strong corporate player. Instead I often chose a more innovative or entrepreneurial path than my boss appreciated.

3. I wish I had paid full attention to corporate signals and political changes in the corporations in which I worked. My attention has caused setbacks in my career from time to time.

5. I wish I had taken a career interruption and/or moved out of the workforce for a period of time to better serve the needs of my family.

6. I wish I had gone back to school and restarted another career path that was better suited to me.

7. I wish I could have worked harder than I did, but it was not worth compromising my family or personal needs to work so many hours on the job.

8. I wish I had chosen my friends and allies more carefully, as their lack of support has cost me a measure of success in my career.

9. I wish I had developed stronger skills at managing others along the way.

10. I wish I had been more of a maverick and did work that suited me rather than doing what the boss says.

11. I wish I had made my own path and did work that suited me creatively or entrepreneurially rather than working for a corporation.

${ }^{a}$ Note: The numbers in bold represent items used to create the scale for that factor. 
TABLE 2

Correlations, Means, and Standard Deviations of Study Variables

\begin{tabular}{|c|c|c|c|c|c|c|c|c|c|c|c|c|c|c|}
\hline & Mean & SD & 1 & 2 & 3 & 4 & 5 & 6 & 7 & 8 & 9 & 10 & 11 & 12 \\
\hline 1. Objective career regrets & 2.53 & .92 & $(.81)$ & & & & & & & & & & & \\
\hline 2. Subjective career regrets & 2.48 & .81 & $.62 * *$ & $(.77)$ & & & & & & & & & & \\
\hline 3. Gender $(1=\mathrm{M}, 2=\mathrm{F})$ & 1.48 & .50 & $-.07 * *$ & .05 & - & & & & & & & & & \\
\hline 4. Children $(1=\mathrm{Y}, 2=\mathrm{N})$ & 1.54 & .50 & .02 & $-.13 * *$ & $-.08 * *$ & - & & & & & & & & \\
\hline 5. Elder care $(1=\mathrm{Y}, 2=\mathrm{N})$ & 1.89 & .31 & .01 & -.03 & -.04 & .00 & - & & & & & & & \\
\hline 6. Household income & 4.86 & 2.09 & -.03 & $-.07 * *$ & $-.11 * *$ & $-.07 * *$ & -.01 & - & & & & & & \\
\hline 7. Education & 4.19 & 1.62 & .03 & $-.13^{* *}$ & -.05 & .05 & -.02 & $.33 * *$ & - & & & & & \\
\hline 8. Hours worked & 42.26 & 11.46 & .03 & -.04 & $-.27 * *$ & $.08^{* *}$ & .01 & $.16^{* *}$ & $.11^{* *}$ & - & & & & \\
\hline 9. Worked at different firms & 2.24 & 1.42 & $.07 *$ & -.04 & $-.08 * *$ & .01 & -.02 & $.16^{* *}$ & $.15^{* *}$ & .04 & - & & & \\
\hline 10. Changed job for family needs & 2.12 & 1.43 & .04 & $.20 * *$ & $.18^{* *}$ & $-.32 * *$ & $-.08 * *$ & $-.08 * *$ & $-.07 * *$ & $-.21 * *$ & $.08 * *$ & - & & \\
\hline 11. Leveled off $(0=Y, 1=N)$ & .63 & .48 & $-.10 * *$ & $-.10 * *$ & $.11 * *$ & -.02 & $.06^{*}$ & -.01 & .01 & .00 & -.03 & -.00 & - & \\
\hline 12. Laid off $(0=Y, 1=N)$ & .72 & .45 & $-.18 * *$ & $-.08 * *$ & $.13^{* *}$ & $-.08 * *$ & .03 & $.05^{*}$ & $.07 * *$ & -.01 & $-.19 *$ & .00 & $.17 * *$ & - \\
\hline
\end{tabular}

Note: The numbers on the diagonal represent the coefficient alpha for the scale.

$* p<.05$.

$* * p<.01$ 
TABLE 3

Regression Equations

\begin{tabular}{|c|c|}
\hline Ages 348 & younger ( $\mathrm{N}$ \\
\hline Objective & Subjective \\
\hline Regrets & Regrets \\
\hline
\end{tabular}

Ages 35-44 ( $\mathrm{N}=449)$

Objective Subjective

Ages 45-54 ( $\mathrm{N}=418)$

Ages 55 \& older $(\mathrm{N}=158)$

Regrets Regrets

Regrets Regrets

Objective Subjective

Objective Subjective

Personal Background Variables:

Gender $(1=\mathrm{M}, 2=\mathrm{F})$

Children $(1=\mathrm{Y}, 2=\mathrm{N})$

Elder care $(1=\mathrm{Y}, 2=\mathrm{N})$

Household income

$\begin{array}{ll}-.04 & .01 \\ -.03 & -.09 \\ -.11 * & -.10 * \\ -.10 * & -.07\end{array}$

$\begin{array}{rr}-.02 & .04 \\ .03 & -.04 \\ .05 & -.03 \\ .05 & .04\end{array}$

Regrets Regrets

Regrets Regrets

Human Capital Variables:

Education

Hours worked

$\begin{array}{ll}.10 & -.09\end{array}$

$-.06 \quad-.01$

$\begin{array}{ll}.03 & -.11 * \\ -.01 & .03\end{array}$

$\begin{array}{lr}-.17 * * & -.04 \\ .03 & -.09 \\ .06 & .07 \\ -.07 & -.02\end{array}$

$.05 \quad .10$

$.06 \quad-.07$

$.07 \quad-.00$

Career Strategies \& Events Variables:

\section{Worked at different firms}

Changed job for family needs

$\begin{array}{ll}.08 & -.10 * \\ .07 & .24 * * \\ -.04 & -.04 \\ -.13 * * & -.06 \\ & \\ .07 * * & .14 * * \\ .04 & .12\end{array}$

$\begin{array}{ll}.03 & -.02 \\ -.04 & .18 * * \\ -.12 * * & -.14 * * \\ -.23 * * & -.12 * \\ & \\ .09 * * & .09 \\ .07 & .07\end{array}$

.01

$01-.19 * *$

$.12 \quad .06$

Leveled off $(0=\mathrm{Y}, 1=\mathrm{N})$

Laid off $(0=\mathrm{Y}, 1=\mathrm{N})$

$\mathrm{R}^{2}$

Adjusted $\mathrm{R}^{2}$

.04

.07

.07

$\begin{array}{llll}.06 & .03 & -.26 * * & -.21 * \\ .09 & .08 & .17 * & .21 * * \\ -.07 & -.11 * & -.03 & -.07 \\ -.11 * & -.05 & -.38 * * & -.21 * \\ & & & \\ .07 * * & .08 * * & .23 * * & .15 * * \\ .05 & .06 & .17 & .09\end{array}$

Note: The regression coefficients shown are standardized.

$* p<.05$.

$* * p<.01$. 